\title{
Is the Recovery of Transition Countries Possible on the New Global Stage and How?
}

\author{
${ }^{1}$ Anđelko S. Lojpur, ${ }^{2}$ Ivan Radević, ${ }^{3}$ Anja A. Lojpur, ${ }^{4}$ Nikola Martinović \\ 1, 2 Faculty of Economics, University of Montenegro, Podgorica, Montenegro \\ ${ }^{3}$ Central Bank of Montenegro, Podgorica, Montenegro \\ ${ }^{4}$ Crnogorska komercijalna banka, member of OTP Group, Podgorica, Montenegro
}

\begin{abstract}
When it comes to finding a new development formula in transition countries, it is worrisome that a well-trodden development paradigm lacks in today's multipolar world. Therefore, overcoming the apparent deadlock in the development of transition countries is possible only through the "new" order, or, in other words, through acceptance of the "new" economic paradigm of development. This paper aims to answer the key question regarding the development perspectives of the transition countries, "Can the transition countries (region) ever catch up with the living standards of the world's most advanced market economies?" In this sense, the research of a new development pattern involving reactivation of the entrepreneurial economy is the answer to the second question: given the omnipresent globalization, is it possible to reverse the concept of development in the transition to greater equality of wealth in the world; therefore, this paper openly advocates for the re-industrialization of transition countries.
\end{abstract}

Keywords: Transition, Globalization, Competitiveness, New Development Paradigm, ReIndustrialization

\section{Introduction}

With the onset of the transition process in the late 1980s and early 1990s, former socialist, mostly underdeveloped countries, were struck by the severe and precarious blows of the globalization process. The economic globalization has become the dominant characteristic of modern capitalism (Jessua, $C ; 2008 ; 48$ ) and a success indicator on a global level. In a global context, an ever-more intense competition threatens the survival of entire national economies and businesses that are unable to transform, innovate, fail to be productive and respond to regional pressures.

Three-decades of experience shows the "labor pains" of establishing a market economy, which takes particularly long in countries that have accepted the "ten commandments" from the "New Economic Bible," that is based on the dominant policy of (neo) liberal economic ideology advocated by the IMF, the World Bank, etc. Namely, after the collapse of communism in the late 1980s, the countries of Eastern and Central Europe "embraced" the Western model of the free market without any reservations. The financial and economic crisis, which was generated at and came from the "West," hit these countries at full blast. In this regard, if their transitional achievements are evaluated today and compared to the expectations, it is evident that many other transition countries face similar problems: high balance of payments deficit, high external debts, an unbalanced budget, high unemployment rate, unstable economic structure, slow and insufficient institutional reforms, negative demographic trends, and so on. Better to say, the type of globalization and the "introduction" of the market economy in most of the economies transitioning from communism to the market (economy) did not produce the results promised by the political elites. The question regarding the much-needed abandonment of the obsolete development paradigm in the short run could be: what are the critical assumptions for the stabilization of economic development in these 
countries, and in the long term - is it possible and how to devise a concept of development corresponding to global development trends, while respecting the specifics of each national economy?

The transition "vortex" and radical changes that occurred in the real economy at the end of the $20^{\text {th }}$ and the beginning of the $21^{\text {st }}$ century inevitably prompted an assessment of the existing economic concepts and the dominant practice they rely on. Following the above questions and the evaluations of failed expectations regarding the overall improvement, a question concerning the stage of transition countries seems to remain unresolved. In this regard, J. Stiglitz says that the world has gone through dramatic changes that have "flattened" it. Still, the gap between rich and poor countries widens equally on both sides, as well as between those countries that can effectively compete on the global level and the ones that cannot (J. Stiglitz, (a) 2007; 57). Also, T. Piketty stresses his doubt in a possible convergence in the dynamics of wealth distribution on a global level by pointing out that there is no natural, spontaneous process to prevent destabilizing, inegalitarian forces from prevailing permanently (T. Piketty; 2014; 32). Professor Jurčić points out that global operations are the chance and constraint for the development of national economies, but "in the light of things, big economies benefit, while the costs of globalization are dispersed through a large number of small countries" $(2014 ; 126 ; 126)$.

Undoubtedly, considering a future choice transition countries face, it is worrying that the inequality has become the Achilles' heel of the modern economy (R. Sennett, 2007; 48). At the same time, most regions from the Southern and Eastern Europe (Latvia, Slovakia, Hungary, Bulgaria, Romania, Greece, Spain, the Western Balkans, etc.) are considered vulnerable and will continue to suffer the negative consequences of globalization (see O. Mirić, 2009, 94-95). This may be attributed to unimplemented structural changes and inadequate industrial policies, which further suggest the relatively high share of activities with a small additional value, unskilled labor, insufficient use of the educated workforce, low level of direct foreign investments, etc.

\section{Transition Countries In Globalization}

At the beginning of the 1990s, undeveloped countries and transition economies found themselves under harsh and uncertain blows of two dominant processes: the external process of globalization and the internal process of transition. The "idea" of implementing the globalization on business operations was prompted by neo-liberal capitalism. The so-called "new world order" brought the rise of multinational corporations, mainly from the most prosperous countries such as the United States. Under the guise of a promising globalization, with the purpose of generating top profit, the free flow of goods and capital is at the same time supported by legal frameworks and measures of the World Bank, the WTO, and the IMF.

Economic globalization has become the dominant feature of modern capitalism. That is the most significant social and economic change ever since the industrial revolution. As a sociologist $A$. Giddens explains, it represents the spatial and temporal reduction that is associated with the accelerated communication, which further enables accelerated exchange of knowledge and culture (see Lojpur; Drašković, 2013). At the same time, prompted by the extremely rapid and powerful technological changes, which made the world relatively "smaller" ("closer"), globalization was imposed as one of the most significant economic and political forces of this century, to whose powerful influence underdeveloped countries cannot resist.

Today, the questions that inevitably arise from this paper for the creators of economic policy and the governments, of both the leading financial "powers" and the poor countries, is whether the ultimate breakdown of the (institutional-monistic) ideology of the omnipotence of "invisible hands" will also mean the end of the economic neo-liberalism, i.e., the one that started with the "Reagan era" and continued through the era of "Thatcherism." Practice and theory proved that the above pattern was wrong and the creators of neo-liberalism admitted that too; however, it is unclear why the world's "financial policemen," personified by the IMF and the World Bank turned a blind eye to 
the destructive events and how they failed to foresee them? Could this be explained by their inability, which is the consequence of circumstances in which financial globalization has overgrown the international institutions that were supposed to regulate it? To be more pragmatic, what will all this mean for countries that have long been in transition, exposed to the pressures of a radical neoliberal concept from the very beginning and that is now on the road to EU accession? Finally, which way and how the countries that are halfway to adopt the values of civil society and democracy should move on. It has long been believed that it is possible to achieve democracy through a higher level of "market enlightenment," i.e., through liberalism and free-market only. The utopian vision of the free market and the alleged "pure" competition preached that such a situation fits individual freedoms "naturally." Such a devious elitist individualism has been imposed on many countries and to the general public as a social and civilizational norm. The reforming practice of many post-socialist and other underdeveloped countries severely constricted the proclaimed principle. Because neoliberalism was used as a hegemonic order of the rich, minority, as well as the policy of protecting the poor and unprotected national majority, changed whenever necessary (see Lojpur, Drašković, 2016).

Correspondingly, practice and theoretical researches show that globalization provides more opportunities to larger companies and national economies that manage to gain a competitive edge on a global market. At the same time, globalization in such economies results in structural changes, and consumers benefit from lower prices and a more comprehensive selection. In this sense, countries from the northeast of the EU, i.e., Finland, Sweden, Denmark, the United Kingdom, and Ireland, found themselves in a better position and will continue profiting due to the high competitiveness and highly educated workforce, better participation in the high-tech industry, and so on. See Table 1 for rankings of countries according to the index and sub-indices of globalization. ${ }^{1}$

Table 1: Ranking of countries according to the index and sub-indices of globalization

\begin{tabular}{|c|c|c|c|c|c|c|c|c|c|c|c|c|}
\hline $\begin{array}{c}\text { Country/ } \\
\text { Index of } \\
\text { globalization }\end{array}$ & $\begin{array}{l}\frac{D}{C} \\
\frac{0}{0} \\
\frac{1}{d} \\
\stackrel{N}{N} \\
\frac{3}{3}\end{array}$ & 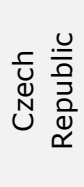 & $\begin{array}{l}\frac{2}{\sqrt{n}} \\
\text { D } \\
5 \\
\text { I }\end{array}$ & $\begin{array}{l}\frac{\pi}{\frac{\pi}{\pi}} \\
\frac{0}{n}\end{array}$ & $\begin{array}{l}\frac{\pi}{\frac{\pi}{2}} \\
\frac{\partial}{n}\end{array}$ & $\begin{array}{l}\stackrel{0}{+0} \\
\frac{\pi}{0} \\
\frac{0}{U}\end{array}$ & 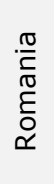 & $\begin{array}{l}\frac{\pi}{0} \\
\frac{1}{d} \\
\text { ஸे }\end{array}$ & 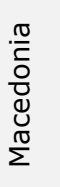 & 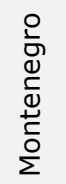 & 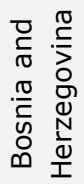 & 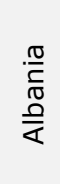 \\
\hline Global & 1 & 13 & 14 & 21 & 25 & 28 & 33 & 37 & 55 & 57 & 66 & 74 \\
\hline Economic & 8 & 13 & 15 & 21 & 32 & 37 & 46 & 38 & 43 & 27 & 97 & 58 \\
\hline Social & 4 & 34 & 43 & 38 & 30 & 33 & 59 & 69 & 91 & 60 & 99 & 93 \\
\hline Political & 8 & 28 & 18 & 43 & 46 & 41 & 25 & 36 & 79 & 127 & 68 & 115 \\
\hline
\end{tabular}

According to the index of globalization (KOF) for 2018, the following countries are globalized: Switzerland ranked first, followed by the Netherlands, Belgium, Sweden, the UK, Denmark, Austria, France, Finland and so on. When it comes to transition countries, as shown in Table 1, some of which are already EU members, they rank as follows: the Czech Republic is top-ranked on the thirteenth position, followed by Hungary (14), Slovakia (21), Slovenia (25), Croatia (28), Romania (33), Serbia (37), Macedonia (55), Montenegro (66), etc. If this indicator is aligned to indicators such as the level of global competitiveness, GDP per capita, etc., the implication is that countries that are actively involved in the globalization and have accepted its principles achieve better results. Generally speaking, we could say that globalization is not an obstacle to development. Examples of such growth are the so-called "Asian tigers" (South Korea, Hong Kong, Taiwan), as well as other emerging industrialized countries that have managed to get closer and reach the development level of the leading advanced countries, on the waves of globalization. In that sense and to sum up, based on the global ranking, it is evident that a state does not necessarily have to be large, nor rich in natural resources to be successful. Also, there are positive examples of some of the most populous countries in the world, such as China and India, that implemented in-depth and comprehensive reforms of the economic system in the context of globalization.

\footnotetext{
${ }^{1}$ Switzerland was the first-ranked country according to the globalization index (KOF).
} 
T. Domazet points out the ubiquitous complexity of transition in the globalization by using Croatia as an example to emphasize: "We should not be fooled by the illusion that we have done a lot by allowing global forces to act freely on our territory. It is much more important, yet, bad for us, that we failed to strengthen our presence in the world, as Finland or Ireland did in Europe or Hong Kong, Singapore and China in Asia. Without such presence, globalization limits our power and inhibits the possibility of action too"(T. Domazet; 2007). Finally, the conclusion could be that the dynamics of the development of individual national economies, especially of smaller and less resilient ones, will depend more on their ability to gain a competitive edge through the use of knowledge. Furthermore, this can be accomplished if countries succeed in using their existing comparative advantages thoroughly and "find" new ones. In the long run, the main force that genuinely leads to a greater equality is the diffusion of knowledge and skills (T. Piketty; $30 ; 33$ ).

\section{Has There Been Was a True Progress in the Process of Transition?}

"Can the transition region ever catch up with the living standard of the world's most advanced market economies?" is the question that was set up in one of the reports of the European Bank for Reconstruction and Development, and it still stands. ${ }^{2}$ This document clearly states that the economic growth of these countries is still below the pre-crisis level, that many of them have "turned their backs" on the reforms that could otherwise boost the economy of the former Eastern Bloc countries. The "shock," as further stated in the report, has triggered doubts about the ability of these countries to get back on the right track of reforms, and to catch up with the living standards of advanced countries. At the same time, given the stagnation in reforms, it is logical to question how and when transition countries will manage to restore the so-called under-reform traps.

To support the thesis that the "under reform trap" is common for a large number of countries, we cite professor D. Đuričin, an expert in transition matters, who uses Serbia as an example and states that Serbia's main problem is the so-called output gap; i.e., the level of economic activity that is below any level. "Serbian economy is impotent and out of tune"; "Also, the climate (regulations + institutions + dominant strategy of economic entities) in which economic policy is being implemented is inadequate. This particularly applies to institutions such as the securities commission, the stock market and the central bank, as well as to the mindset of business entities in the so-called "Burazerska privatizacija" (corrupt privatization) (see D. Đuričin, 3). Regarding Croatia's continuous loss of industrial substance and tradition, ž. Primorac points out that the unfortunate situation in the industrial sector is a consequence of several factors. "Naturally, some of them are caused by the global economic and financial crisis, but, to some extent, the economic policy of the country is responsible for negative industrial development. The management of the economic sector and the overall economic policy is inadequate, incompetent and inconsistent" (Ž. Primorac, 2013; 9). Furthermore, this means that countries with emerging institutional and transitional forms and the global environment failed to generate production factors, i.e., the comparative advantages they have (land, labor, capital), which resulted in lower "potential income." Thus, for example, instead of hiring employees in industries where they could be most effective, the industries collapsed and that was most often referred to as the deindustrialization process, although very distinct from what this concept means in the advanced western economies. Contrary to such an idea of transition, we emphasize the following statement of prof. LJ. Jurčić: "It is difficult to find a developed country that has not developed its industry beforehand and which even today does not invest significant efforts to make its industry even more competitive in the world" (see Lj. Jurčić, 2014; 121). A phenomenon is present in most countries, both the developed ones, as well as in those in transition. At the same time, we notice the reduction of the share of industry and employees in these countries, accompanied by an absolute decrease in added value, which deepens the crisis in those countries, unlike in developed ones. For example, at the beginning of the 1990s, the share of industry in

2 Transition Report 2013; "Stuck in transition", European Bank for Reconstruction and Development. 
Montenegrin GDP amounted to more than 35\%, with about 56,000 employees. In contrast, in 2015, this share was reduced to about $11 \%$, and the processing industry amounted to only $4.2 \%$ of GDP. ${ }^{3}$

Furthermore, creators of industrial and economic policies and developing countries should consider the inevitable regularity of globalization, where it has failed to reduce poverty, and it has not succeeded in securing the stability either (Stiglitz, 2002;20). To be more precise, globalization will not make itself more human, more productive, or more equitable, so transition countries will have to stand up for themselves. In the long run, the main force that genuinely leads to greater equality is the diffusion of knowledge and skills (T. Piketty; 2103; 33). This leads to the conclusion that the dynamics of the development of individual national economies will depend on their ability and perseverance to gain a competitive edge based on knowledge. This, again, although it is not the primary subject of this paper, points to the need for a review of several basic concepts of economic theory, especially if we bear in mind that economic rationality in transition countries should be followed by democratic rationality too.

On the other hand, not only transition countries face problems. Namely, the global challenges the $\mathrm{EU}$ is facing have remained the same, but they gained in strength and complexity; to mention some of them: the continuous economic strengthening of the rising economies, the reorganization of finances on the global scale, climate change and resource constraints. The mentioned tendencies, communicated in the form of EU strategies such as, for example, "Strategy 2020", carry particular weight in countries that have already "joined" the EU, but are often treated as "poor relatives." To support the above, Table 2 shows the review of the progress made by a group of transition countries presented in the form of the so-called transition scores: 4

Table 2: Progress made in the group of transition countries

\begin{tabular}{|c|c|c|c|c|c|c|c|c|c|c|c|c|}
\hline \multirow{2}{*}{$\begin{array}{l}\text { Country / } \\
\text { Key Factors }\end{array}$} & \multicolumn{2}{|c|}{ Competitive } & \multicolumn{2}{|c|}{$\begin{array}{c}\text { Well- } \\
\text { governed }\end{array}$} & \multicolumn{2}{|c|}{ Green } & \multicolumn{2}{|c|}{ Inclusive } & \multicolumn{2}{|c|}{ Resilient } & \multicolumn{2}{|c|}{ Integrated } \\
\hline & 2018 & 2017 & 2018 & 2017 & 2018 & 2017 & 2018 & 2017 & 2018 & 2017 & 2018 & 2017 \\
\hline Albania & 5.0 & 4.9 & 5.1 & 5.1 & 4.4 & 4.4 & 4.8 & 4.8 & 5.3 & 5.2 & 5.7 & 5.7 \\
\hline $\begin{array}{l}\text { Bosnia and } \\
\text { Herzegovina }\end{array}$ & 4.9 & 4.9 & 4.6 & 4.8 & 5.3 & 5.0 & 5.3 & 5.3 & 5.8 & 5.8. & 5.4 & 5.3 \\
\hline Croatia & 5.8 & 5.9 & 6.0 & 6.2 & 6.5 & 6.2 & 6.3 & 6.4 & 7.3 & 7.2 & 6.9 & 6.9 \\
\hline Bulgaria & 5.9 & 5.9 & 5.7 & 5.8 & 6.2 & 6.0 & 6.4 & 6.2 & 6.8 & 6.8 & 6.9 & 6.8 \\
\hline Estonia & 7.7 & 7.7 & 8.3 & 8.4 & 6.7 & 6.7 & 8.1 & 8.1 & 7.8 & 7.8 & 7.7 & 7.7 \\
\hline Macedonia & 5.7 & 5.6 & 5.8 & 5.8 & 4.9 & 4.9 & 5.6 & 5.6 & 5.7 & 5.6 & 6.1 & 6.0 \\
\hline Hungary & 6.5 & 6.5 & 5.9 & 5.9 & 6.3 & 6.3 & 6.8 & 6.8 & 6.8 & 6.8 & 7.5 & 7.6 \\
\hline Lithuania & 6.4 & 6.4 & 6.8 & 6.9 & 6.8 & 6.5 & 7.0 & 6.9 & 6.4 & 7.4 & 7.2 & 7.5 \\
\hline Montenegro & 5.2 & 5.2 & 5.9 & 5.8 & 5.3 & 5.3 & 6.1 & 6.1 & 6.3 & 6.3 & 6.4 & 6.2 \\
\hline Poland & 6.6 & 6.5 & 6.9 & 7.1 & 6.9 & 6.9 & 7.1 & 7.0 & 8.0 & 7.9 & 6.8 & 6.8 \\
\hline Romania & 6.2 & 6.2 & 5.8 & 5.8 & 6.2 & 6.0 & 5.3 & 5.3 & 7.2 & 7.2 & 6.8 & 6.7 \\
\hline Russia & 5.2 & 5.1 & 5.8 & 5.8 & 5.1 & 5.1 & 7.2 & 7.1 & 6.3 & 6.2 & 5.5 & 5.4 \\
\hline Serbia & 5.3 & 5.1 & 5.4 & 5.4 & 5.9 & 5.7 & 5.7 & 6.0 & 5.7 & 5.7 & 6.2 & 6.2 \\
\hline Slovenia & 7.2 & 7.2 & 6.6 & 6.7 & 7.3 & 7.0 & 8.0 & 7.8 & 7.8 & 7.8 & 7.4 & 7.3 \\
\hline Ukraine & 4.7 & 4.6 & 4.6 & 4.4 & 5.8 & 5.8 & 6.0 & 6.0 & 5.6 & 4.9 & 4.9 & 4.9 \\
\hline Turkey & 5.2 & 5.2 & 6.2 & 6.2 & 5.3 & 5.3 & 4.8 & 4.7 & 7.3 & 7.2 & 5.8 & 5.9 \\
\hline
\end{tabular}

Source: EBRD, Transition Report 2018/19; Transition scores: six qualities of a sustainable market economy Based on indicators from Table 2, it is evident that some transition countries lag in key development pillars such as good governance, competitiveness, inclusion and resilience, green economy and integration, innovative Europe, etc. Yet, these are the so-called "soft" factors, or, in other words, non-price factors of competitiveness. Similarly, for this group of countries, the IMF notes in its report

\footnotetext{
${ }^{3}$ See Industrial Policy of Montenegro, draft; June 2015

${ }^{4}$ The EBRD has determined these scores since 1994, covering the period since 1989. The Country-level Transition Indicators indicate how countries move forward through several pillars and allow comparisons between them. Indicators are scores ranging from 1 to 10, with 1 representing the lowest and 10 the highest score. The methodology behind these results has changed over the years, and the biggest changes were in 2017 when the focus shifted entirely to six key factors in a sustainable market economy.
} 
for the Western Balkans, ${ }^{5}$ that in 2002 they reached the level marked as "fairly advanced stage of transition," which would mean an average score of "3" or more, while, for example, new EU members (except Romania and Bulgaria) reached that stage in 1994. The expected convergence is missing. In the same report, the IMF points out that the new EU member states have continued to reduce the lag behind in comparison to EU members, yet the development "gap" between them and the countries of the Western Balkans continues to grow. For sure, there are more causes behind, but this and similar reports list the following as the main reasons for the insufficiently rapid progress of these countries: reform of institutions, infrastructure, and the efficiency of the market of goods, labor market and the financial market. We would add a slower inflow of foreign capital to the above factors, which was initially imposed as the most important driving force of growth, and the lack of the so-called "second" generation reforms, etc.

For a complete analysis of the scope of transition, special attention should be given to the report ${ }^{6}$ providing an overview of several key indicators about the goals set out in the strategy Europe 2020. By comparing indicators of transition countries against developed economies, a significant lag is notable, especially in terms of the efficiency of factors such as: "Digital Agenda for Europe," "Innovation Union" and "Higher Education and Training." Better to say, the advantages provided by information and communication technologies (ICT) and knowledge, in the broadest sense of the term, are not evident. This is especially true with regards to reducing the costs of data exchange, changing work methods, more rational management of resources, and incentives for entrepreneurship. Instead of producing a result of inclusive growth and technological convergence by these factors, the apparent backwardness of these countries could be characterized as a sort of "digital poverty."

Regardless of their "proximity" to the EU, transitioning countries face the requirements posited by the revised Lisbon Strategy, such as: to ensure knowledge and innovation for growth by increasing and improving investment in research and development, to encourage innovation, to apply ICT and improve sustainably by exploiting available resources and the like. Finally, it is not possible to ignore the fact that in today's complex climate, companies compete based on knowledge, and from that, they gain a critical competitive advantage. This makes the situation in transition countries more complex in terms of their future and their governments more responsible ( A.Lojpur, 2013; 3).

The so-far experiences in transition have shown that there may be significant obstacles for the development of entrepreneurship and new businesses in transition economies. Researches that "General Entrepreneurial Monitoring"- GEM ${ }^{7}$ has been conducting for years confirmed that the level of entrepreneurial activity varies across countries, with relatively constant rates. This further confirms that when it comes to economic and industrial policy, the creators of the social order require time and consistency, especially concerning interventions to find long-term incentive factors for entrepreneurship. Researches also confirm that entrepreneurial activity, in different forms (nascent, start-up, intrapreneurship), is positively correlated with economic growth, but this relationship varies along phases of economic development. ${ }^{8}$ Thus, in the latest GEM report, all national economies are classified into three primary groups according to regions and the level of economic development: a) factor-driven economies, including Angola, Botswana, Cameroon, Uganda; India, Iran, Kuwait, Philippines, Vietnam, etc.; b) efficiency-driven economies: South Africa, China, Indonesia, Kazakhstan, Malaysia, Thailand, Argentina, Brazil, Chile, Colombia, Ecuador, Guatemala, Mexico, Panama, Peru, Uruguay, Croatia, Hungary, Lithuania, Poland, Romania, Bosnia and Herzegovina, Georgia, Russia, Turkey, etc.; and c) innovation-driven economies: Australia, Japan, Singapore,

\footnotetext{
${ }^{5}$ Regional Economic Issues, Special Report; The Western Balkans: 15 years of Economic Transition.

6 WEF; The Europe 2020 Competitiveness Report: Building a More Competitive Europe, Edition 2014.

7 In 2014, the GEM review covered 73 countries, 3,936 experts and more than 206,000 participants; the economies account for $72.4 \%$ of the world's population and $90 \%$ of world GDP. The conceptual framework consists of the following 10 components: entrepreneurial finance; education for entrepreneurship; government policy; entrepreneurship programs; research \& development; internal market openness; physical infrastructure; commercial and legal infrastructure; cultural and social norms.

${ }^{8}$ See GEM; p. 20.
} 
Taiwan, Qatar, Austria, Belgium, Denmark, Estonia, Finland, France, Germany, Greece, Ireland, Italy, Latvia, Luxembourg, the Netherlands, Portugal, Slovenia, Slovakia, Spain, Sweden, the UK, Norway, Switzerland, Canada and the United States. Most of the transition countries are in the group of efficiency-driven economies, while Estonia, Latvia, Slovenia and Slovakia are classified as innovation-driven economies.

Further widening of the gap between developed and less developed countries that we have already pointed out, shows that the dynamics of the development of some national economies will increasingly depend on their ability to gain a competitive edge. Otherwise, the success of a national economy or its economic entities, witnessing incredible economic changes in recent years, is being increasingly reflected in the aggregate indicator defined as the level of national competitiveness. See Table 3 for the review of the level of global competitiveness of the leading countries based on the multi-annual Reports for the period 2008-2009 to 2017-18. Apart from that, Table 4 shows a comparison of several regional transition countries against pillars of competitiveness in comparison to first-ranked Switzerland.

Table 3: The ranking of leading countries according to the Global Competitiveness Index in the period 2008-2018

\begin{tabular}{|c|c|c|c|c|c|c|c|c|c|c|}
\hline \multirow[b]{2}{*}{ Country/ } & \multicolumn{10}{|c|}{ The ranking of leading countries according to the Global Competitiveness Index } \\
\hline & $\begin{array}{c}2017- \\
18\end{array}$ & $\begin{array}{c}2016- \\
17\end{array}$ & $\begin{array}{c}2015- \\
16\end{array}$ & $\begin{array}{c}2014- \\
15\end{array}$ & $\begin{array}{c}2013- \\
14\end{array}$ & $\begin{array}{c}2012- \\
13\end{array}$ & $\begin{array}{c}\text { 2011- } \\
12\end{array}$ & $\begin{array}{c}2010- \\
11\end{array}$ & $\begin{array}{c}2009- \\
10\end{array}$ & $\begin{array}{c}2008 \\
-09 \\
\end{array}$ \\
\hline Switzerland & 1 & 1 & 1 & 1 & 1 & 1 & 1 & 1 & 1 & 2 \\
\hline Singapore & 3 & 2 & 2 & 2 & 2 & 2 & 2 & 3 & 3 & 5 \\
\hline Sweden & 7 & 6 & 9 & 10 & 6 & 4 & 3 & 2 & 4 & 4 \\
\hline Finland & 10 & 10 & 8 & 4 & 3 & 3 & 4 & 7 & 6 & 6 \\
\hline USA & 2 & 3 & 3 & 3 & 5 & 7 & 5 & 4 & 2 & 1 \\
\hline Germany & 5 & 5 & 4 & 5 & 4 & 6 & 6 & 5 & 7 & 7 \\
\hline Netherlands & 4 & 4 & 5 & 8 & 8 & 5 & 7 & 8 & 10 & 8 \\
\hline Denmark & 12 & 12 & 12 & 13 & 15 & 12 & 8 & 9 & 5 & 3 \\
\hline Japan & 9 & 8 & 6 & 6 & 9 & 10 & 9 & 6 & 8 & 9 \\
\hline $\begin{array}{l}\text { Great } \\
\text { Britain }\end{array}$ & 8 & 7 & 10 & 9 & 10 & 8 & 10 & 12 & 13 & 12 \\
\hline Hong Kong & 6 & 9 & 7 & 7 & 7 & 9 & 11 & 11 & 11 & 11 \\
\hline Canada & 14 & 15 & 13 & 15 & 14 & 14 & 12 & 10 & 9 & 10 \\
\hline
\end{tabular}

Source: Global Competitiveness Report; The World Economic Forum; several years.

Table 4: Competitiveness level for Switzerland, Bosnia and Herzegovina, Montenegro, Serbia, Croatia and Slovenia according to the report 2017/18

\begin{tabular}{|c|c|c|c|c|c|c|}
\hline Countries & Switzerland & $\begin{array}{l}\text { Bosnia and } \\
\text { Herzegovina }\end{array}$ & Montenegro & Serbia & Croatia & Slovenia \\
\hline $\begin{array}{l}\text { Global Competitiveness } \\
\text { Index GCI - Rank }\end{array}$ & 1 & 103 & 77 & 78 & 74 & 48 \\
\hline Basic requirements & 1 & 91 & 80 & 74 & 58 & 35 \\
\hline $1^{\text {st }}$ pillar: Institutions & 4 & 126 & 66 & 104 & 102 & 56 \\
\hline $2^{\text {nd }}$ pillar: Infrastructure & 6 & 100 & 70 & 75 & 48 & 39 \\
\hline $\begin{array}{l}3^{\text {rd }} \text { pillar: Macroeconomic } \\
\text { environment }\end{array}$ & 3 & 64 & 116 & 72 & 60 & 40 \\
\hline $\begin{array}{l}4^{\text {th }} \text { Pillar: Health and } \\
\text { primary education }\end{array}$ & 2 & 56 & 62 & 52 & 4 & 14 \\
\hline Efficiency enhancers & 3 & 100 & 72 & 82 & 69 & 53 \\
\hline $\begin{array}{l}5^{\text {th }} \text { pillar: Higher } \\
\text { education \&training }\end{array}$ & 5 & 91 & 61 & 59 & 60 & 24 \\
\hline $\begin{array}{l}6^{\text {th }} \text { pillar: Goods } \\
\text { market efficiency }\end{array}$ & 6 & 126 & 65 & 110 & 99 & 40 \\
\hline $\begin{array}{l}7^{\text {th }} \text { Pillar: Labor market } \\
\text { efficiency }\end{array}$ & 1 & 123 & 74 & 92 & 107 & 82 \\
\hline
\end{tabular}


Anđelko S. Lojpur, Ivan Radević, Anja A. Lojpur, Nikola Martinović

Is the Recovery of Transition Countries Possible on the New Global Stage and How?

\begin{tabular}{|c|c|c|c|c|c|c|}
\hline $\begin{array}{l}8^{\text {th }} \text { pillar: Financial } \\
\text { market development }\end{array}$ & 8 & 104 & 47 & 101 & 95 & 106 \\
\hline $\begin{array}{l}9^{\text {th }} \text { pillar: Technology } \\
\text { readiness }\end{array}$ & 2 & 69 & 48 & 72 & 43 & 35 \\
\hline $10^{\text {th }}$ pillar: Market size & 39 & 97 & 128 & 74 & 77 & 82 \\
\hline $\begin{array}{l}\text { Factors of innovation } \\
\text { and sophistication }\end{array}$ & 1 & 119 & 92 & 104. & 99 & 37 \\
\hline $\begin{array}{l}11^{\text {th }} \text { pillar: Business } \\
\text { sophistication }\end{array}$ & 1 & 115 & 101 & 110 & 82 & 41 \\
\hline $12^{\text {th }}$ pillar: Innovation & 1 & 123 & 91 & 95 & 106 & 35 \\
\hline
\end{tabular}

To sum up, based on the data from the Report on Global Competitiveness 2008-2018, generated following earlier methodology (Table 3), Switzerland is at the top for the ninth year in a row (before that it was second). There was a change in the second position as Singapore dropped to third place after ranking second for six successive reports and the US rose to the position. The Netherlands is in fourth place and Germany ranked fifth. According to the latest report, Estonia is the best ranked among transition countries taking the $29^{\text {th }}$ place, followed by the Czech Republic in the $31^{\text {st }}$ position. Apart from indicating significant backwardness of the regional countries in comparison with the leading countries in terms of the global level of competitiveness, according to data from the Table 4, majority of regional countries lag in key pillars such as "Business sophistication" and "Innovation" in relation to their general ranking.

Finally, looking at the decades-long achievements of transition countries that are a subject of this paper, it is apparent that we cannot speak of convergence. Better said, the "development gap" between developed and transition countries continues to widen. Likewise, the reforms that had begun in the socialist countries, especially in the Western Balkans, were halted in mid-2000 and can generally be regarded as incomplete. Thus, according to the currently projected growth rates, the Western Balkans' economies will curtail only a small portion of the existing difference in per capita income in comparison to the advanced economies by 2030. It was inconsistency rather than the nature of reforms that made these countries victims of their "reform fatigue," which can be explained by the absence of radical structural transformation, resistance to private ownership, with many state enterprises that are "survivors" and continue to be a burden on public finances and allocation of resources. Furthermore, bureaucratic procedures and corruption continue to hinder economic activity; corporate governance reform is absent, and so on. ${ }^{9}$

\section{Reindustrialization as a Basis of a New Development Paradigm}

The onset of the global economic crisis showed that developed countries have problems, not just transition countries. Thus, according to strategically designed vision that is formalized in critical documents of the European social market economy for the $21^{\text {st }}$ century, the EU economy ought to be smart, sustainable and inclusive ${ }^{10}$. In one of the EU's previous annual competitiveness reports (2014), it was pointed out that "Europe is emerging from the crisis and signs of slow recovery are visible. Nevertheless, although we have made progress, we have not yet reached the level we anticipated and which we need to be able to create new jobs". ${ }^{11}$ In the same report, the following recommendations were listed as necessary to increase the competitiveness in the EU Member States: a) first, more investment is required across all economic sectors; b) second, growth requires investment, and investments require capital; c) the third message is that we (the EU) should highlight the importance of innovation for growth; d) the fourth message is that Europe lags in terms of competitiveness due to high energy prices; e) the fifth message is imperative for European businesses to make better access to markets and become fully integrated into the global value chain;

\footnotetext{
${ }^{9}$ See: The Western Balkans: 15 years of Economic Transition.

10 "Europe 2020 Strategy."

${ }^{11}$ See: Competitiveness Reports Press Briefing; 11 September 2014, p. 1-15.
} 
f) the sixth imperative is for EU member states to improve the quality of public administration. The inefficiency of public administration and the legal system is recognized as a key obstacle to improving EU competitiveness.

The emphasis on economic growth is undoubtedly a key priority. In that sense, transition countries are no different from other economies, so now it is even more apparent why the re-industrialization is at the very top of the open problems in the EU and most transition countries. When it comes to Croatia, Ž. Primorac points out that re-industrialization is "very important for the future, long-term development of the country, but also for overcoming the current economic crisis." In doing so, he does not fail to point out that "at the end of the previous century, and especially at the beginning of this century, there were major changes in the concept of industrial development in a way that" traditional industries are repressed and replaced with new technologies... "(see: Ž. Primorac, 2013; $5-9)$.

It turned out that in today's multipolar world, there are no embedded development paradigms; the only way to pull the transition countries out of the crisis is in the form of a new order, the one that will not have much socialism in itself. In this sense, we believe the following should be identified as conceptual governmental courses of action in transition countries in the form of a single conceptual development framework or development paradigm. That is, a) building a functional institutional infrastructure: b) real institutional changes towards the establishment of institutional pluralism c) new state role; d) "creative destruction" completion of the de-industrialization process; e) new industrial policies; f) regional clusters; $g$ ) abandoning the myth of foreign investments; $h$ ) translating absolute and comparative into competitive advantage; i) reduction of inequality; $j$ ) the process of technological convergence; k) the new role of "social capital"; I) reactivating the entrepreneurial economy. We will briefly comment on each of these components:

a) Building a functional institutional infrastructure: The practice of the developed and the less developed countries equally shown that all development models that have fallen into the "institutional vacuum" or ignored institutions have, in principle, been hit by the crisis. D. Rodrick believes that the mutual relationship and the influence of political and economic institutions must contribute to the establishment of institutional competition and to a functional institutional structure that contributes to socio-economic development $(2000 ; 5-7)$. It is precisely the example of transition countries that showed how "bad institutions induce people to get rich through corruptive actions that reallocate the existing income and wealth, but fail to increase employment or social wealth," says M. Arsić. ${ }^{12}$

b) The new role of the state. In this sense, our starting point is that "the state is wrong," but the market is even more imperfect. In that sense, a new role of the state in the shortest could be characterized as the abandonment of the function (role) of the leading entrepreneur and its transition to the service of correcting market anomalies and failures. However, both the "anti-market" and "anti-state" positions have something in common, i.e., they need to restrain and take control of the "maddening" financial capitalism and to modernize the tax and transfer system fundamentally, that is in the core of a modern "welfare state" (See: A.Lojpur; 2015; 24).

c) "Creative Destruction" (Schumpeter, 1942) as the completion of the process of "deindustrialization." The transition countries referred to in this paper are, according to all crucial features, small economies. They have to be open to the global environment, but they cannot affect the international flows of capital significantly or influence the overall trends in the worldwide market. They have generally achieved a certain level of stability. Still, they found themselves in a phase when economic growth can no longer be secured based on instruments of macroeconomic policy. This would mean a total break with an unproductive "smokestack industry," the shutdown of large business systems, i.e., former socialist giants that still endure in some transition countries mainly due to non-economic reasons, such as "political ones" and the like.

12 See: "Serbia needs a rocket pace of growth"; Politika, Belgrade; January 15, 2016 
d) New industrial policies. Re-industrialization in a way that the dynamics of economic growth would not be possible if the continuity in development policy persists, especially not with the outdated institutional and organizational basis. This means that it is necessary to devise a valid industrial strategy in the long run, especially when it comes to small national economies that depend heavily on the global market. The market itself cannot solve the developmental issues of such countries; this is not to deny a certain kind of critically necessary protection of the domestic industry and the gradual opening to the world, including the removal of many business barriers (see $A$. Lojpur, 2015, 25).

e) Regional clusters. Several countries cannot transform themselves promptly into entrepreneurial economies, mostly due to, among other things, lack of "economies of scale," unbalanced regional development, crumbled industry, high mortality of the family-owned business and the like. Instead, it is possible to encourage a new entrepreneurial infrastructure that will, in its initial phase, produce advantages of a knowledge-based economy, and strengthen it to reach certain forms of connectivity at a regional or even at the supra-national level in the form of innovative-entrepreneurial clusters.

f) Abandoning the myth of foreign investments. Experiences from the past taught us it is unrealistic to expect from the developed countries or from any other entity to provide necessary funds for reforms or reindustrialization. It all points to the conclusion that "financing" of development must rely mostly on domestic savings. First of all, transition countries need to create conditions for a profitable investment of domestic capital, but it is not a matter, as often heard, of the quantity or sufficiency but rather of capital management?

g) Translating absolute and comparative into competitive advantage. To be able to understand the matters discussed in this paper thoroughly, we consider as especially important to understand the difference between the comparative and competitive advantages and their connection with the competitiveness of the national economy. Namely, the success achieved so far in underdeveloped countries was based mostly on a combination of vast natural and other domestic resources, government aid, cheap labor, or some other inherited advantages, which we usually refer to as absolute and comparative advantages. However, business operations today show that these benefits are no longer sufficient to achieve and preserve the high living standards of citizens. At the same time, efforts to turn comparative advantages, which can otherwise be easily supported, into competitive ones, cannot always succeed. As the rankings of global competitiveness (WEF) show, many rich countries in terms of natural resources are ranked at the very bottom.

h) Reduction of inequality. The convergence of inequalities is possible only by the gradual establishment of a new development paradigm embracing the "knowledge economy." We shall begin with the fact that that knowledge and innovations played a crucial role in the development of civilization. The process of diffusion of knowledge and investments in professional training has been imposed as the main force of convergence (see T. Piketty, 2014; 32-33). In the last decade, we witnessed the breakthrough of two giants of the world's economy: China and India, mostly due to their opening up. So, these are no longer just developing countries, but full-fledged nations investing significant efforts in the knowledge-based society, in terms of the education of their people and the preparation of future innovations (C. Jessua, 2008; 47; 47).

i) Process of technological convergence. "Advancement in the direction of technological rationality," T. Piketty points out, "would automatically lead to the triumph of human capital over financial capital and real estate, to the triumph of capable managers over the shareholders with deep pockets, the victory of competences over the origins" (T. Piketty, 2014; 33; ). With accelerated globalization and technological revolution in recent decades, knowledge has become a key factor of competitiveness, and, based on that, new models of economic growth are being shaped. The core of this strategy consists of four fundamental pillars: a) labor force, b) modern and adequate 
information infrastructure, c) efficient innovation system, and d) developed a national institutional framework. ${ }^{13}$

j) New role of social capital. "If, as I believe, the global economy is powered by technology, then knowledge is its precious metal"; says K. Ohmae. This is about the rise of "human capital," where as the starting premise, we state that a developed strategic approach to the development of human potentials in a small underdeveloped country can result not just in national recognition in regional frameworks, but significantly accelerate its economic development too. In that sense, a new model of economic growth should be based on the use of knowledge and this basis its ability to establish a new economic development paradigm, where the maximum growth rate of social production, forced loyalty, subordination and hegemony, raw functional authority and the like will no longer be so important. With this, even less developed countries, the so-called periphery ones, would be able to free themselves of the world centers of economic and political power control. For example, for years, Finland has been one of the leading countries ranking for competitiveness by taking advantage of the benefits of a knowledge-based economy, where a large portion of merit rests on a permanent insistence on innovation (K. Ohmae, 2007; 17; 17).

k) Reactivating the entrepreneurial economy. In the majority of transition countries, the tradition of collective entrepreneurship has caused problems in the inauguration of individual entrepreneurship, the start-up of family businesses, and so on. Low level of entrepreneurship in transition countries is a logical result of the so-called necessity entrepreneurship, contrary to the developed countries of a market economy where the opportunity entrepreneurship prevails (D. Deakins: 39). Finally, for the first time in human history, the process of changing the economic world based on entrepreneurship and innovation has confirmed that prosperity and total wealth of a nation does not depend on the existing wealth.

\section{Conclusion}

So far, the rather modest success of the underdeveloped, former socialist countries affected by the transition has mostly been based on a combination of vast natural and other resources, government aid, or some other inherited comparative advantage. Regardless of the impression that today's networked economy provides the same opportunities to everyone, there is evident stagnation and further widening of the gap in terms of the achieved level of development and inequality in wealth between the developed countries and a group of many underdeveloped countries, i.e., most of the transition countries.

The choice in terms of conceptual development that transition countries face is rather narrow; they will have to "turn to apply the (most) modern technologies and scientific achievements to get closer to advanced countries. At the same time, taking into account the economic growth of transition countries in the post-crisis period, the incomplete processes and the lag in the reforms, the relaunch of fundamental structural changes is inevitable. Our commitment to the design of a new industrial policy, at the same time, presupposes the search for valid modalities of opposing imposed globalization and rising divergence. This requirement assumes the acceptance of a new developmental conceptual framework, the initiation of the reindustrialization process new development base, as already explained in the paper. To avoid new wanderings, especially when it comes to the transition countries in the process of EU accession, the newly developed strategies should be based on the priority guidelines established by the EU. That is, the developmental framework should include the knowledge society; single market; creating a climate for the development of entrepreneurship; labor market as a factor of social cohesion and the environmentally sustainable development.

\section{References}

${ }^{13}$ See: Building Knowledge Economies, p. 23-28. 
- $\quad$ Deakins, D; Freed, M.: "Preduzetništvo male firme"; Datastatus, Belgrade, 2012.

- $\quad$ Domazet, T.: "Economika - politika. Kako dalje? "; Hrvatsko društvo ekonomista; Zagreb, 2007; 375

- Đuričin, D, Nacrt strategije reindustrijalizacije Serbije, Belgrade

- Jessua, C. (2008), La capitalisme, translation, Zagreb

- Jurčić, L: "Industrijska politika u globalnim procesima "; Acta Economica; Banja Luka, no.13; 2014.

- Lanvin, B .: "The World's Most Teach-Ready Countries 2015"; April, 2015

- Lojpur, A.: "Reindustrijalizacija - između zakašnjelog buđenja i nove paradigme privrednog rasta"; Acta Economica, Banja Luka, no. 22, 2015.

- Lojpur, A., Drašković, V.: "Nerazvijene zemlje u uslovima globalizacije - traženje valjanog razvojnog obrasca"; VIII International Conference on Corporate Governance; Teslić, May; 2013.

- Lojpur A., Drašković, V.: "Zemlje u tranziciji u slovima globalizacije - budućnost koju je neko drugi osmislio"; Teslić, May; pp.253-269; 2016.

- Lojpur, A., Lalević, A.: "Reindustrialization as the backbone of the new development paradigm in the transition countries"; Book of Abstracts; 13 International Scientific Conference - Economic and Social Development; Barcelona; April, 2016 p.45.

- Mirić. O: "Regionalna politika kao motor ekonomskog razvoja"; European Movement, Belgrade, 2009.

- Ohmae, K.: "The next global stage", translation, Mate, Zagreb; 2007.

- Penava, M., Druzic, M .: "Industrijska politika Hrvatske - pogled s aspekta deindustrijalizacija"; Razvojni potencijali hrvatskog gospodarstva, Faculty of Economy, Zagreb, 2014.

- M.: "Makroekonomija hrvastke deindustrijalizacije"; Faculty of Economics, Zagreb, 2014.

- Primorac, Ž. "Hrvatskoj je potrebna nova industrijska politika "; Financing; Banja Luka, No; 2; .2013. Crossref

- Piketty; T.: "Kapital u 21. stoljeću"; translation; Zagreb, Profile, 2014.

- Rodrik, D.: "Institutions for High Quality Growth: What They Are and How to Acquire Them"; Studies in Comparatives International Development, Vol.35: 2000. Crossref

- Rodrik, d.: "Industrial policy: Do not ask why, ask how"; Middle East Development Journal, no.1. 2009. Crossref

- Rodrik, D.: "One Economies - many recipes; globalization, institutions and economic growth "; Princeton University Press; 2007. Crossref

- Sennett, R.: "The Culture of the New Capitalism ", translation, Arhipelag, Belgrade, 2007.

- $\quad$ Stiglitz, J.: (a) "Making Globalization Work ", Penguin Books; 2007.

- Stiglitz, J.: (b) "Globalization and Its Discontents ", WWNorton \& Company, translation by SBM, Belgrade, 2002.

- Vasiček, D.: "Računovodstveno i finansijsko izvještavanje u funkciji upravljanja u javnom sektoru "; Hrvatska javna uprava; No.2; p.393-420; 2009.

- Vietor, HKR: "How countries compete; Strategy, Structure, and Governance in the Global Economy ", Harvard Business School Publishing, (translation), Mate, Zagreb, 2010.

- Vujovic, D.: " Održivost rasta i razvoja tokom tranzicije "; Ekonomika preduzeća, Beograd, vol, 54, br.5-5, p.224-233; 2006.

- Walser, C-D: "Industrial Policy in the Process of Transition", Dissertation, Stuttgart, 1999.

- The Western Balkans: 15 years of Economic Transition, International Monetary Fund, Washington, DC; March 2015.

- Zapadni Balkan 2004.godine; Pomoć, kohezija i nove granice Evrope, ESI; November, 2002

- Industrijska politika Crne Gore do 2019-2023, Ministry of Finance of the Government of Montenegro, Podgorica, June, 2019.

- Global Competitiveness Report; Multi-annual; the World Economic Forum.

- WEF; the Europe 2020 Competitiveness Report: Building a More Competitive Europe, Edition 2014.

- Global Innovation Index 2018; energizing the World with Innovation; WIPO; https://www.globalinnovationindex.org/gii-2018-report;

- $\quad$ Global Entrepreneurship Monitor, GEM Report, 2014.

- Regional Economic Prospects and EBRD Countries of Operations, November 2015.

- World Bank (2007), Building Knowledge Economies, Advanced Strategies for Development, Washington. 